Finally, one important point must not be forgotten. As mentioned above, considerable stores of vitamin A can be accumulated in the liver. An excellent way to dispose of any hypothetical surplus of carrots therefore would be to stimulate immediate consumption. The increased storage of vitamin A in the livers of the population would represent a real national asset. Not only would we be in a better position to withstand any shortage of vitamin A which might occur during the following months, but we would also probably benefit immediately by improved dark adaptation, with a corresponding reduction in road and other accidents occurring after 'black-out'.

\title{
FLORA AND FAUNA OF THE INNER AND OUTER HEBRIDES
}

\author{
By Prof. J. W. Heslop Harrison, F.R.S.
}

$\mathrm{I}^{\mathrm{N}}$ Nature of June 17, 1939, p. 1004, was published an account of King's College (University of Durham) Biological Expeditions to the Inner and Outer Hebrides, bringing the records of our results up to the end of 1938 . Since then the work has proceeded steadily, although not to completion; nevertheless, in view of present circumstances, it seems best to supply a similar summary of the fruits of our 1939 and 1940 investigations.

Despite obvious difficulties, we have spent considerable periods during those years on the Islands. Thus, in the late spring of 1939 we visited Mull, Coll and Tiree, continuing our work in summer by exploring Lewis, Great Bernera, Little Bernera, Harris, Berneray, Pabbay (Sound of Harris), North Uist, South Uist, Fuday, Fiaray, Barra, Muldoanich, Vatersay, Flodday, Sandray and Pabbay (Barra Isles). Similarly, in the early summer of 1940, we concentrated our efforts on Tiree, Coll and Gunna, returning later to Coll to examine more closely certain aspects of its flora, and then ending the season by exploring the Isles of Benbecula, South Uist and Colonsay.

As usual, both the flora and fauna of the islands were studied, but the plants proved the most productive of novelties. In particular, our researches have added greatly to our knowledge of the distribution of several important elements in the British flora: (1) those of boreal and alpine proclivities, (2) those of southern and southwestern origin, and (3) those of American affinities.

Before we commenced our work, the majority of species belonging to the first-named section was supposed, of necessity, to be restricted to the mountains of Lewis and Harris. Now it has been shown that a new 'focus' for such plants exists in the Beinn Mhor, Feaveallach, Hecla area of South Uist. Upon this more or less unglaciated mountain massif we have observed up to date, Thalictrum alpinum, Cochlearia alpina, Saxifraga oppositifolia,
S. stellaris, Oxyria digyna, Epilobium alsinifolium, Saussurea alpina, Salix herbacea, Alopecurus alpina, Deschampsia alpina, Poa alpina, Carex vaginata, $C$. rupestris, $C$. rariflora and $C$. rigida. In addition, we have detected there a second and very peculiar species of Epilobium with fleshy, characteristic leaves. This was not in flower when collected: nor have specimens brought home alive flowered since. Almost certainly the plant is the arctic Epilobium Hornemanni.

In extending the list of boreal and alpine forms, other Outer Islands have added their quota as, for example, Silene acaulis (Berneray and Mingulay), Cerastium arcticum (at a low elevation on Rueval, Benbecula), Oxyria digyna (Mingulay and Pabbay) Ajuga pyramidalis (Barra and Muldoanich), and Salix herbacea (Barra and North Uist). Of importance, too, is the fact that we have also collected Silene acaulis and Polygonum viviparum at sea-level at Uig in the west of Lewis and on Little Bernera off the same coast.

Furthermore, in spite of the low altitude of Coll, its rocky outcrops and sand dunes have been shown to support strong colonies of Saxifraga hypnoides, Ajuga pyramidalis and Carex rigida.

Of southern and south-western plants, Juncus capitatus has been taken on Barra, whilst not far away the muddy shores of Loch St. Clair have yielded Illecebrum verticillatum (a plant already recorded for Eriskay by Goodrich-Freer) to several members of our party. On Fuday we had the pleasure of seeing a single plant of Cicendia pusilla, whilst South Uist likewise produced the same plant, with Herniaria glabra var. ciliata in addition. In this connexion, too, we should like to emphasize the confirmation of the occurrence of Epilobium tetragonum in the Outer Isles, with the significant addition of $E$. Lamyi on Fuday and South Uist.

For its headquarters in the Hebrides, the 
American element possesses the Isle of Coll. There we had the privilege of marvelling at the abundance of Eriocaulon septangulare in a dozen lochs, in the Loch a Mhill Aird, Loch Ronard and Loch na Cloiche area. More widely spread in the island

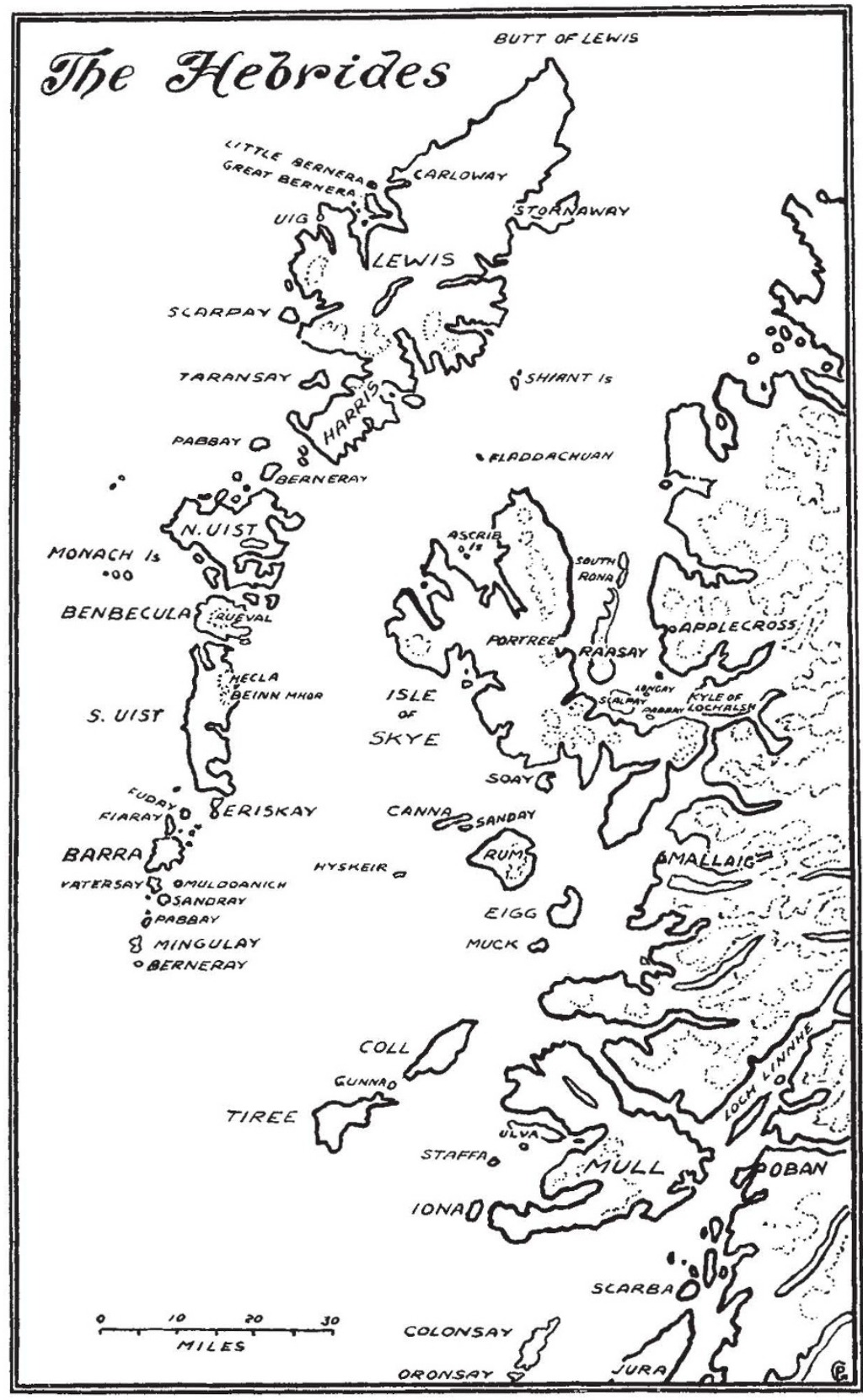

aware, on a very limited habitat on a slope leading from the south-east margin of Loch Cliad. The distribution of the fourth member of the same group, Naias flexilis, is different; it has been dredged from various lochs between Howmore and Stoneybridge on South Uist, and from Loch Fada on Colonsay, the forms from the two islands differing somewhat. In all probability there should be added a fifth member to this select band in the form of Epilobium adenocaulon which has turned up, significantly enough, on Coll and South Uist. However, recognizing its presence as a colonist in the south of England, we do not, for the moment, stress the fact.

From the above remarks it will be clear that the deductions put forward in our previous report continue to receive weighty support. It seems certain that, as we have urged previously, the Alpine and northern forms as well as more tender southern species, possibly of diverse origins, have survived the Glacial Period in a much more extensive 'Long Island' than exists to-day. Moreover, other pictures are forming. As our researches have progressed we have been increasingly impressed by the very marked relationships existing between the flora of Coll, Tiree and Gunna on one hand and that of the Outer Isles, south of the mountain group of South Uist, on the other. This similarity stands in obvious contrast with the many differences observed between the floras of the northern and southern halves of the Outer Group of islands. Without doubt, these are definite indications that, when the flora of the Outer Hebrides was being stabilized, conditions within that group were far from being uniform

was the Irish ladies' tresses orchid (Spiranthes Romanzoffiana (stricta) which flourishes in two distinct forms on the grassy moorlands lying between Loch Cliad in the centre, and Sorisdale and Bousd in the extreme north-east. The third American plant favouring Coll, Sisyrinchium angustifolium, can only be found, so far as we are throughout. This position, too, receives confirmation from the distribution of such Lepidoptera as Argynnis aglaia, Pieris napi, Eumenis semele, Eubolia mensuraria and of other insect species. Utilizing the whole of the available evidence, we are driven to the conclusion that the Coll, Gunna and Tiree of that period had much freer communi- 
cations with the southern Outer Isles than with the northern series.

Further, the concentration of the American element in Coll recalls a similar grouping in Ireland, thereby indicating the possibility of a land connexion between Coll and Ireland long after the Outer Islands had parted company with both. This view is backed up by the fact that quite recently we have discovered the Irish race of the greasy fritillary butterfly (Euphydryas aurtnia var. praeclara) in Coll and Tiree and the Irish burnet (Zygona purpuralis) on Gunna.

On the other hand, it will be remembered that in our earlier contribution we used the endemic Rosa Sherardi var. glabrata as a pointer in respect to what islands should be regarded of mainland proclivities, or to have been detached recently therefrom. One

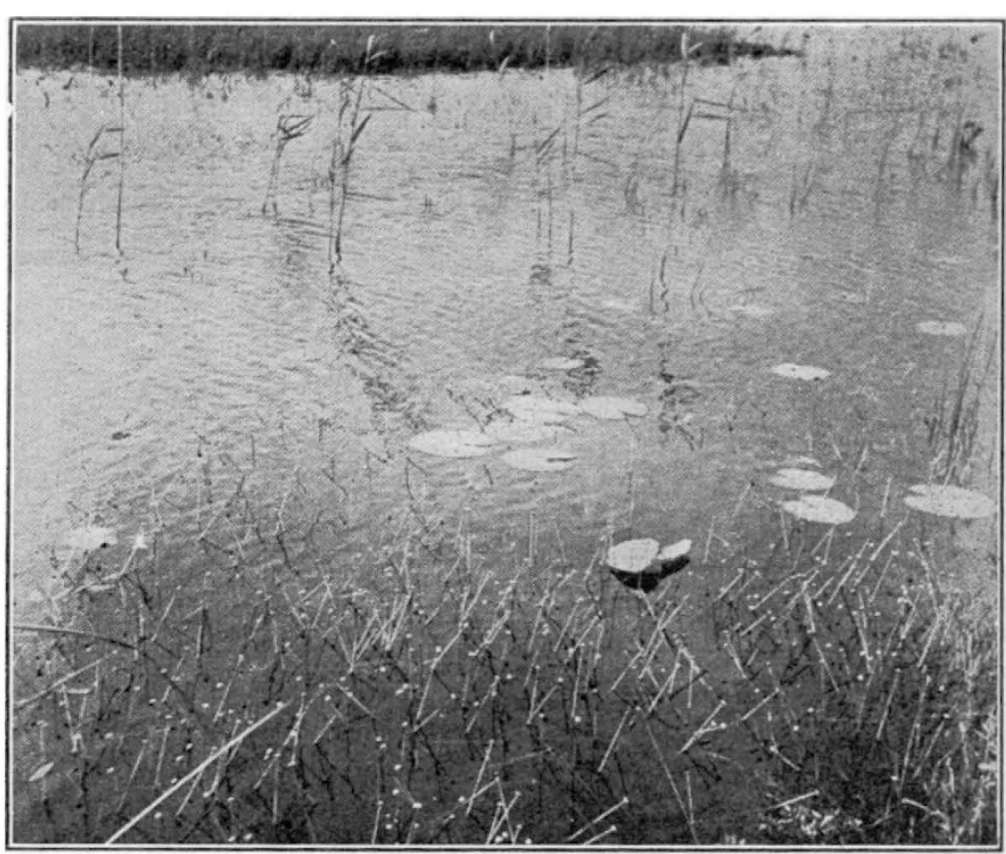

Fig. 1.

Pipe-wort (Eriocaulon septangulare), Loch a Mrrul AIrd, ISLE OF COLS.

of our workers, Dr. W. A. Clark, collected this rose on Mull in 1939, so that, accepting our test, Mull lines up with the mainland. If appeal be made to the insects, the same result appears, for the Hebridean bee, Bombus smithianus, dominant in the Coll group, fails in Mull, to be replaced, as on Skye, by its ally Bombus muscorum var. pallidus, a form almost certainly derived from mainland sources.

In conclusion, it is not proposed here to repeat the argument employed in the 1939 paper to



Fig. 2.

Loch Ronard, Isle of Coll. support our views concerning the Pleistocene and early Holocene history and geography of the Hebrides, but we do wish to urge that our work supplies weighty reasons for a rearrangement of the accepted limits of the Watsonian vice-counties into which, for biological purposes, the British Isles are divided. As we have accumulated our mass of facts, we have steadily been forced to the view that the acceptance of the Isles of Skye, Raasay, South Rona, Scalpay, Pabbay, Longay, Soay, Rhum, Canna, Eigg, Muck and Hyskeir as forming vice-county 104 cannot be defended, for it conceals the very serious discrepancies between the flora and fauna of the first seven and those of the last five. Similarly, we believe that the linking of Mull and its adjacent islets with Coll, Gunna and Tiree as vicecounty 103 is likewise biogeographically unsound. Attaching due weight to the unmistakable connexion between the floras and faunas of Coll, Tiree, Gunna, Rhum, Eigg, Canna, Muck and Hyskeir and those of the Outer Isles, we suggest that a proposal to label the first three islands as vicecounty $110 \mathrm{~A}$ and the remainder as vice-county $110 \mathrm{~B}$ should be deemed worthy of very careful and favourable consideration. 